\title{
Effect of predation by juvenile Pacific salmon on marine harpacticoid copepods. I. Comparisons of patterns of copepod mortality with patterns of salmon consumption
}

\author{
Donald G. Webb* \\ Department of Oceanography, University of British Columbia, Vancouver, British Columbia, Canada V6T 1W5
}

\begin{abstract}
The impact of predation by juvenile chum Oncorhynchus keta (Walbaum) and pink $O$. gorbuscha (Walbaum) salmon on harpacticoid copepods inhabiting a shallow subtidal seagrass Zostera marina L. bed on Roberts Bank, British Columbia, Canada, was examined. Previous studies of the impact of juvenile salmonid predation on harpacticoid communities have yielded contradictory results and have been based on indirect and weak evidence. The influence of salmon predation on the dynamics of the copepod community was examined by comparing patterns of copepod mortality to patterns of salmonid consumption. Samples of Zostera leaves and underlying sediment were collected at ca 2 wk intervals from late January to early July in 1986 and 1987 for estimation of harpacticoid copepod abundance. Collections for estimation of juvenile salmonid abundance and gut contents were made concurrently at a low tide refuge adjacent to the seagrass bed. Juvenile chum and pink salmon were found mainly to consume 3 harpacticoid copepod species $(>75 \%$ by number in gut contents in both years): Harpacticus uniremis Kröyer, Tisbe cf. furcata (Baird) and Zaus aurelii Poppe. Using a simple and robust deterministic, compartmental population dynamics model, mortality of adults and potential adults of these 3 species between sampling dates was estimated. In comparison with an index of consumption estimated for the salmonid population, temporal patterns of copepod mortality generally did not correspond to temporal patterns of salmonid consumption. This lack of correspondence indicates salmonid consumption did not cause observed declines in $H$. uniremis, $T$. cf. furcata and $Z$. aurelii abundance during the sampling season in either year.
\end{abstract}

\section{INTRODUCTION}

Marine harpacticoid copepods are a favoured prey resource for juvenile Pacific salmon Oncorhynchus spp. during their marine nearshore-residence period (e.g. Kaczynski et al. 1973, Mason 1974, Feller \& Kaczynski 1975, Healey 1979, Godin 1981, Cordell 1986), before the fish start feeding planktonically offshore at a size of 60 to $80 \mathrm{~mm}$ (Healey 1980, Simenstad et al. 1982). The effect of juvenile salmon predation on harpacticoid copepods has been estimated in 2 studies. Healey (1979) concluded that juvenile chum salmon have a severe impact on the density of selected copepod species and suggested that the fish may be food-limited through preference of rare harpacticoid species as

\footnotetext{
- Present address: Department of Oceanography, Dalhousie University, Halifax, Nova Scotia, Canada B3H 4J1
}

prey. His results were based on a bioenergetic analysis of salmonid consumption and an estimate of harpacticoid prey densities by Sibert (1979). Cordell (1986), however, found no evidence that juvenile chum and pink salmon were food-limited and he suggested that the salmon have little effect on harpacticoid densities. However, a number of weaknesses are associated with both studies.

Healey (1979) analyzed the feeding and production of juvenile chum salmon Oncorhynchus keta (Walbaum) preying on harpacticoids in the Nanaimo estuary, British Columbia, Canada. He observed that the major harpacticoid prey for juvenile chum salmon was Harpacticus uniremis Kröyer, a relatively large and rare component of the sediment copepod community (Sibert 1979). Copepods of the genus Harpacticus, however, are typically epiphytic (Hicks 1985a). Healey (1979) stated that the salmonids were seined at low tide 
while the fish inhabited tidal channels containing eelgrass Zostera marina L., which is common in the lower reaches of the estuary (Naiman \& Sibert 1979). Sibert's (1979) cores were obtained throughout the estuary in unvegetated sediments. It is unclear, therefore, whether the gut contents of the chum reflected feeding in the estuary proper and whether Sibert's measurements of copepod density accurately estimated true population abundance. Also, Healey's estimate of predatory mortality is based on a crude bioenergetic model of fish feeding parameters and ration over the entire sampling season. Therefore, any discussion regarding food limitation of fish and effects on harpacticoid populations based on these results is speculative.

Cordell (1986) studied the impact of chum and pink Oncorhynchus gorbuscha (Walbaum) salmon on harpacticoids at Spuhn Island, Alaska. He concluded that the juveniles of both salmon species were not foodlimited by copepod abundance and that predation had little effect on the prey species. He found that the copepods most commonly preyed upon were Harpacticus uniremis and Tisbe spp. (the genus Tisbe is generally also epiphytic; Hicks 1985a). Cordell observed no trend in a 'fullness index' of the salmon over his study period. Also, he suggested that predation by salmon was unimportant to the harpacticoid populations, based on selection for specific life history stages by the fish and the presence of peaks in copepod density under high predation pressure. Cordell based his estimates of copepod density on epibenthic pump samples in an area of 'macrophyte' cover on the assumption that this technique would better sample the harpacticoid community 'available' to salmon. While this technique may efficiently sample epibenthic and migrating (see Palmer 1988) copepods, it may underestimate the abundance of epiphytic species. In addition, active entry into the water column by epiphytic and sediment-dwelling harpacticoids may be confined to certain species and life history stages within species (e.g. Bell et al. 1988, D'Amours 1988, Walters 1988). Therefore, epibenthic pump sampling may give an inaccurate indication of harpacticoid densities and population structure for the purpose of estimating the impact of predation. Finally, Cordell's estimate of predator impact is based on changes in the specific composition of gut contents with no regard for changes in fish abundance and consumption rates. No firm conclusion can be reached from either study (Healey 1979, Cordell 1986) as to the effect of juvenile salmon predation on harpacticoid copepods.

I tested in 2 ways the hypothesis that predation by juvenile salmonids controls the abundance of harpacticoid copepod populations. This paper compares patterns of feeding by juvenile salmon on harpacticoids to patterns of mortality in the copepod populations. A companion paper considers the response of the harpacticoid community in the absence of large epibenthic predators (Webb 1991).

\section{MATERIALS AND METHODS}

Study area. This study was conducted on Roberts Bank, British Columbia, Canada (Fig. 1). The area is vegetated with seagrasses (see Harrison 1987) and is a foraging ground for large numbers of juvenile salmonids (Gordon \& Levings 1984). The fish feed heavily

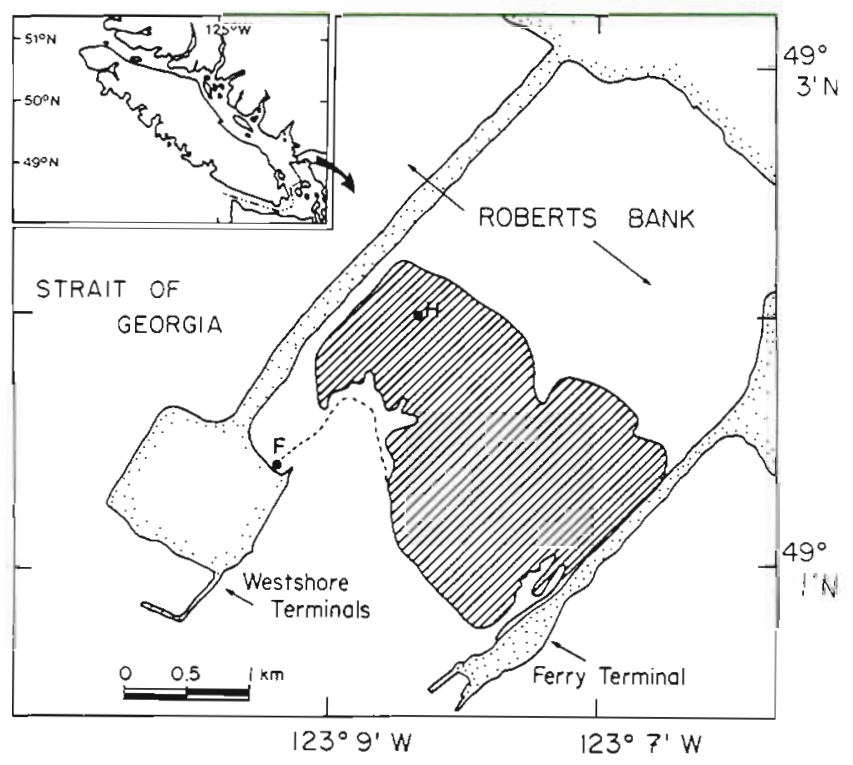

Fig. 1. Station locations on Roberts Bank, British Columbia, Canada, Stn F: location of fish sampling; Stn H: location of harpacticoid copepod sample collection. Hatched area indicates extent of Zostera marina bed (after Harrison 1987).

Dotted line shows seaward limit of shallow subtidal flat

on harpacticoid copepods ( $>79 \%$ by number of prey items) (D'Amours 1987).

Separate stations were sampled for harpacticoid copepods and juvenile salmon. Harpacticoid copepods were sampled at $\mathrm{Stn} \mathrm{H}$ (Fig. 1). Stn $\mathrm{H}$ is located within a Zostera marina L. bed. Water depth at low tide is ca $5 \mathrm{~cm}$ (D'Amours 1987. Harrison 1987, pers. obs.). Maximum water depth at high tide is ca $3.2 \mathrm{~m}$. Sediment is fine sand (Swinbanks \& Luternauer 1987). Since the purpose of the harpacticoid copepod sampling was to establish temporal rather than spatial patterns in copepod abundance, only this one station was occupied allowing a large number of replicate samples to be collected on each date.

Sampling for juvenile salmon was conducted at a low tide refuge (Stn F) (Fig. 1). This station was selected for 
estimation of juvenile salmonid abundance and sampling of gut contents after the fish were forced out of the seagrass beds by the ebbing tide. Abundance could then be estimated while the fish were concentrated and gut content composition reflected feeding within the seagrass beds (Webb 1989).

Harpacticoid mortality. Mortality rates were estimated for 3 species: Harpacticus uniremis Kröyer, Tisbe cf. furcata (Baird) and Zaus aurelii Poppe. This was due to their known prevalence in salmon gut contents ( $D^{\prime}$ Amours 1987). Since it was suspected that these 3 species were primarily epiphytic on seagrass leaves, both seagrass leaves and the underlying sediment were sampled.

Harpacticoid sampling and abundance estimation: Six leaves were sampled from randomly chosen Zostera marina shoots within $20 \mathrm{~m}$ of $\mathrm{Stn} \mathrm{H}$, at ca $2 \mathrm{wk}$ intervals from late January to early July in both 1986 and 1987 . For each selected shoot, the longest leaf was enclosed within a $30 \mathrm{~cm}$ long, $4 \mathrm{~cm}$ i.d. PVC tube with a screw cap of $63 \mu \mathrm{m}$ mesh. The sampler contents were rinsed into a jar and preserved. Relative age of the sampled leaf within the shoot was determined morphologically by observing the point of leaf insertion in the sheath in relation to the oldest (basal) leaf and the alternating pattern of leaf emergence.

To sample sediment-dwelling copepods, 6 cores were taken on each sampling date. Cores were taken at random coordinates within a $0.25 \mathrm{~m}^{2}$ quadrat divided into 100 squares, placed $1 \mathrm{~m}$ south of Stn $\mathrm{H}$. The cores were $5.3 \mathrm{~cm}^{2}$ in area and $5 \mathrm{~cm}$ deep. Cores were extruded, placed into jars and preserved.

In the laboratory, leaf samples were shaken 5 times to remove any attached copepods. This procedure is over $99 \%$ efficient in retrieval (Webb 1989). Length and width measurements were made on each leaf and surface area (of both sides) was estimated arithmetically. In each sample, all copepodites of Harpacticus uniremis, Tisbe cf. furcata and Zaus aurelii were counted. The first 50 copepodites of each species encountered, if present, were identified to copepodite stage and gender, if possible. Total abundance of each stage and gender was estimated as a proportion of the total number of copepodites.

Copepods were obtained from the core samples by swirling the sediment 5 times and each time decanting the supernatant through a $63 \mu \mathrm{m}$ sieve. This procedure is over $99 \%$ efficient in recovery (Webb 1989). Analysis then proceeded identically as with the leaf samples.

Abundances in each sample (leaf and sediment) were converted to number $\mathrm{cm}^{-2}$ sediment area. This was accomplished for harpacticoids in the leaf samples using a methodology employing intrashoot copepod distributions, relative age of leaf samples, and seagrass shoot density (Webb 1989, 1990). Since core area was known, sediment harpacticoid densities were directly determined.

Harpacticoid mortality model: To estimate the mortality of each species between sampling dates, a simple deterministic, compartmental model, based on that of Argentisi et al. (1974), was used. The form is:

$$
N_{\mathrm{a}, \mathrm{t}+1}=N_{\mathrm{a}, \mathrm{t}}+N_{\mathrm{r}}-M
$$

where $N_{\mathrm{a}}=$ the number of adults; $N_{\mathrm{r}}=$ the number of juveniles that could potentially develop (recruit) into adults during the interval between samples $(t$ to $t+1)$; $M=$ the number of adults and potential adults dying during the interval; and $t=$ the sampling date. As long as the number of adults at each sampling date and the number of potential recruits to the adult population in the interval between sampling dates can be estimated, mortality can be determined. This model was run for each gender of the 3 harpacticoid species in both years. To determine mortality between sampling dates, the mean abundances of adults (summing leaf and sediment densities) on each sampling date were used as $N_{\mathrm{a}}$. Recruitment $\left(N_{\mathrm{r}}\right)$ was projected from juvenile copepodite abundance on the first sampling date and by determining copepodite development time at the mean temperature during the interval between samples. Development times were estimated from predictive equations using temperature as the independent variable (Webb \& Parsons 1988). Mortality of each gender in the interval between samples was simply calculated as potential subtracted from actual adult number. Assumptions inherent in the model are that there is a uniform age distribution in each juvenile stage and that immigration and emigration are equal or zero. This model does not provide stage-specific mortality rates for juveniles over the sampling season since standard methods (e.g. Southwood's graphical method; Southwood 1978) are inaccurate unless the pattern and relative amount of mortality within a stage is known (Sawyer \& Haynes 1984, Hairston \& Twombly 1985). Therefore, calculated spcies mortality rates using the model are restricted to the gross category of adults and potential adults.

Accurate measurement of temperature was required at $\mathrm{Stn} \mathrm{H}$ since it was used to estimate the number of potential adults between sampling dates. Temperature was measured using a Peabody-Ryan recording thermograph for the majority of the sampling season in both years. Temperature records were obtained from February 19 to July 9 in 1986 and February 20 to July 9 in 1987. Data were manually digitized from the thermograph chart paper to the nearest $0.5^{\circ} \mathrm{C}$ at $4 \mathrm{~h}$ intervals. The average of all temperature values extracted between sampling dates was used as the average temperature between sampling dates (Fig. 2). In both years, temperature for the 2 sampling intervals preced- 

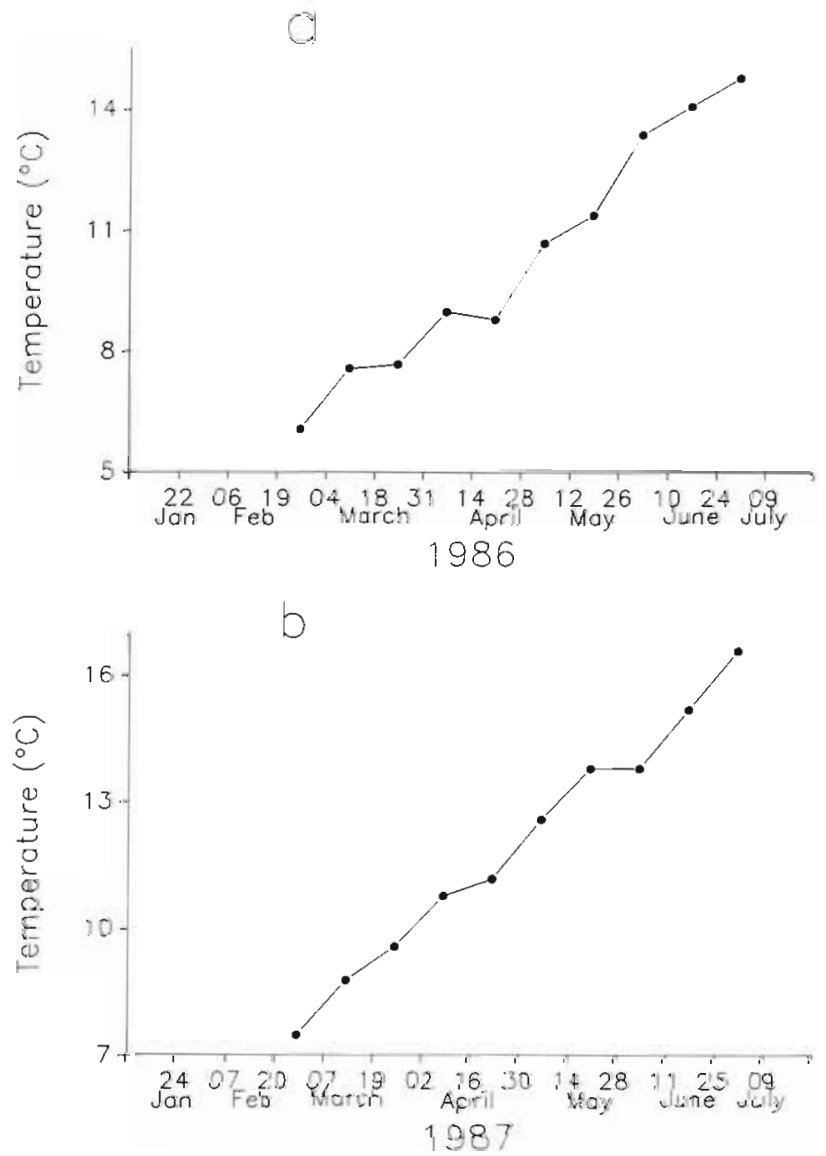

Fig. 2. Mean sediment surface temperature $\left({ }^{\circ} \mathrm{C}\right)$ between harpacticoid copepod sampling dates at Stn $\mathrm{H}$ in (a) 1986 and (b) 1987

ing thermograph emplacement was assumed to be equal to that of the first measured interval. These temperatures were assumed to be those experienced by both seagrass and sediment-dwelling harpacticoids since temperatures obtained with a hand-held thermometer in the water overlying the sediment on each date did not differ significantly from those measured by the thermograph in both years (Webb 1989). Using these temperatures, mean copepodite development times (along with $95 \%$ confidence limits of the predictions) between sampling dates were obtained (see Webb \& Parsons 1988).

The estimated copepodite development times are for females only, and if used to estimate individual copepodite stage durations, isochronal development (equal stage duration) must be assumed (Webb \& Parsons 1988). Therefore, they are not as yet applicable to estimating male development time since males may develop faster than females (see Bergmans 1981). Also, the assumption of isochronal development for copepods may be invalid (Bergmans 1981, Landry 1983). To alleviate these problems, male copepodite development time and differential stage durations were calculated and applied to all 3 species using Bergmans' (1981) data for Tisbe furcata (see Table 1). Table 1 also includes estimated sex ratios for the first 3 copepodite stages of each copepod species, which cannot be sexed externally. Sex ratios were calculated by

Table 1. Estimates of percentage of total development time spent in individual stages for male and female harpacticoid copepods, male copepodite development time as a percentage of female (both after Bergmans 1981 for Tisbe furcata at $18^{\circ} \mathrm{C}$ ) and estimated juvenile copepodite (C1 to $\mathrm{C} 3$ ) sex ratio for Harpacticus uniremis $(\mathrm{H})$, Tisbe cf. furcata $(\mathrm{T})$ and Zaus aurelii (Z). C1 to C5: Copepodites 1 to 5

\begin{tabular}{|c|c|c|c|c|c|c|}
\hline \multirow{2}{*}{ Stage } & \multicolumn{2}{|c|}{$\%$ of total } & \multicolumn{4}{|c|}{ Sex ratio (female: male) } \\
\hline & Female & Male & & $\mathrm{H}$ & $\mathrm{T}$ & Z \\
\hline $\mathrm{Cl}$ & 15.2 & 18.5 & 1986 & $2.8: 1$ & $5.4: 1$ & $1.5: 1$ \\
\hline $\mathrm{C} 2$ & 15.2 & 18.5 & 1987 & $2.4: 1$ & $1.1: 1$ & $1.5: 1$ \\
\hline C3 & 18.2 & 18.5 & & & & \\
\hline C4 & 21.2 & 18.5 & & & & \\
\hline C5 & 30.3 & 25.9 & & & & \\
\hline \multicolumn{7}{|c|}{ Male development time $=81.8 \%$ of female } \\
\hline
\end{tabular}

summing the abundances of each gender in the fourth copepodite stage (C4) throughout the sampling season in each year and then dividing the 2 sums to get a ratio. This approach assumes no gender differential mortality in the C4 stage.

To test the robustness of the model to the assumptions regarding non-isochronal development, unequal gender stage durations and juvenile sex ratios, an empirical sensitivity analysis was performed. The model was rerun with isochronal development, equal development times for each gender and a 1:1 sex ratio for the $\mathrm{C} 1$ to $\mathrm{C} 3$ stages. However, the model was robust and relaxing the assumptions made no difference in the patterns and magnitudes of estimated mortality and therefore the original model was conserved (Webb 1989).

In running the harpacticoid mortality model for Harpacticus uniremis, Tisbe cf. furcata and Zaus aurelii, it was found that using the copepodite development time from the lower $95 \%$ confidence limit of the prediction (i.e. fastest development time at the specified temperature) gave the least number of negative mortality rates (Webb 1989). Therefore, these development times were used in further analysis

On a few occasions, the temporal interval between sampling dates exceeded copepodite development time. This may have led to underestimates of potential adult mortality since uncounted nauplii may have recruited to the adult population. Periods when mortality may have been underestimated are, for females, 
after May 26 in 1986 and after June 11 in 1987. For males, underestimates may have occurred after May 26 in 1986 and May 14 in 1987 . However, for all 3 harpacticoid species, egg numbers were rapidly declining and/or early copepodite stages were not present after these dates indicating that the bulk of adult recruitment was over (Webb 1989). Therefore, this problem was not considered to be severe.

Salmonid abundance and consumption. Samples were collected at ca 2 wk intervals from early March to early July in both years at $\operatorname{Stn} F$, at the daytime low tide on the day after sampling Stn $\mathrm{H}$ in 1986 and on the

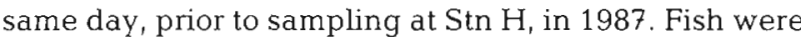
collected by 3 beach seine sets on each sampling date. Catch Per Unit Effort (CPUE, the number of fish in 3 seine sets) was used as an index of abundance of juvenile salmon. CPUE is a valid index of abundance over time if the 'catchability' of the target population does not vary (see Ricker 1975). This seems to be valid in this case since juvenile chum are equally vulnerable to beach seines in the range of 35 to $80 \mathrm{~mm}$ (Bax 1983), which is the size range of fish nearshore at Stn F (see D'Amours 1987).

At least 20 juvenile chum and/or pink salmon, if present, were taken randomly from the first seine catch on each sampling date, and preserved. No regurgitation of stomach contents was observed. In 1986, both juvenile chum and pink were often caught together. Pink salmon were not found in 1987.

Fish samples were analyzed in the laboratory at least 6 mo after preservation. Individual fish were blotted dry and weighed to the nearest $10 \mathrm{mg}$. To analyze gut contents, each fish was cut open and the digestive tract severed anteriorly just behind the gill arches and posteriorly at the anus. The gut along with its contents was blotted dry and weighed to the nearest $50 \mu \mathrm{g}$. The gut contents were then removed and the gut wall reweighed. Food weight was measured by subtraction. Dry body weight and food weight were calculated based on previously estimated empirical relationships between dry weight and wet weight (Webb 1989).

In the gut contents, all copepodites of Harpacticus uniremis, Tisbe cf. furcata and Zaus aurelii were enumerated. The first 50 encountered copepodites of each species were identified to stage and gender, where posible. In some cases (i.e. only adult males and females in gut contents), all the copepodites were staged.

In the 1986 samples, abundances of the 3 studied copepods $\mathrm{mg}^{-1}$ dry food weight in the fish were compared between salmon species starting with the April 29 data, using Student's $t$-test. In cases of heterogeneity of variances (checked using Bartlett's test), the data were $\log _{e}(x+1)$ transformed. The log transformation was successful in removing heteroscedasticity in all cases when applied. All analyses were performed using the MGLH module of SYSTAT (Wilkinson 1985) on a microcomputer.

Using the youngest copepodite stage that was a potential adult for either gender (determined from the development time predictions), the number of adults and potential adults of each gender consumed $\mathrm{h}^{-1}$ fish $^{-1}$ within the intersampling interval was calculated. Unsexable juveniles ( $\mathrm{C} 1$ to $\mathrm{C} 3$ ) were considered to be all of the gender for which mortality was to be calculated. Estimation of consumption $\mathrm{h}^{-1}$ fish $^{-1}$ required a knowledge of copepod abundance in gut contents and gut turnover rate. Number of adults and potential adults $\mathrm{mg}^{-1}$ dry food weight was estimated for each fish. Food evacuation rate ( $\%$ dry body weight $\mathrm{h}^{-1}$ ), depending on temperature, was calculated (see Webb 1989). Assuming the maintenance of a constant food weight in the fish guts, dry food weight consumed $h^{-1}$ was estimated for each date for each fish on the basis of its body weight. Since number of adults and potential adults consumed $\mathrm{mg}^{-1}$ dry food weight was known, number of adults and potential adults consumed $\mathrm{h}^{-1}$ fish $^{-1}$ was calculated for each sampling date. The mean number consumed and the $95 \%$ confidence limits were averaged from consecutive sampling dates. A mean value and error term for number of adults and potential adults consumed $\mathrm{h}^{-1}$ by the salmonid population was obtained by multiplying by the average number of fish obtained on 2 consecutive sampling dates. This value is solely an index of consumption and does not represent harpacticoid consumption on an areal basis (since fish density could not be assessed areally).

Patterns of mortality of adults and potential adults (deaths $\mathrm{cm}^{-2} \mathrm{~d}^{-1}$ ) for each gender of the 3 copepod species were visually compared to patterns in the number of adults and potential adults consumed $\mathrm{h}^{-1}$ by the salmonid population. If patterns of mortality and consumption are dissimilar, then it may be suggested that juvenile salmonid predation alone does not control the abundance of these copepod species. The comparison is valid if fish gut contents reflect feeding in the seagrass bed and there are no changes in food weight in fish during the day. These suppositions are supported by relationships of the abundance of Harpacticus, Tisbe and Zaus in gut contents with tidal height and diurnal patterns in fish gut-content weight (Webb 1989). Harpacticus, Tisbe and Zaus were only present in fish guts at high densities at low tide at Stn F, indicating feeding on these copepod species only in the seagrass bed. Analysis of gut-content weight at $3 \mathrm{~h}$ intervals during 3 separate $24 \mathrm{~h}$ periods showed no significant differences during the daylight hours. Also, the diel tidal pattern has the same period as the sampling schedule, leading to little change between sampling dates in amount of diurnal feeding time in the seagrass bed. 


\section{RESULTS}

In 1986, juvenile chum and pink salmon abundance was maximal on May 27 (Fig. 3a). A small number of fish were present in April with peak densities in May dropping to low levels in June. Chum salmon were more abundant than pink in April and June samples
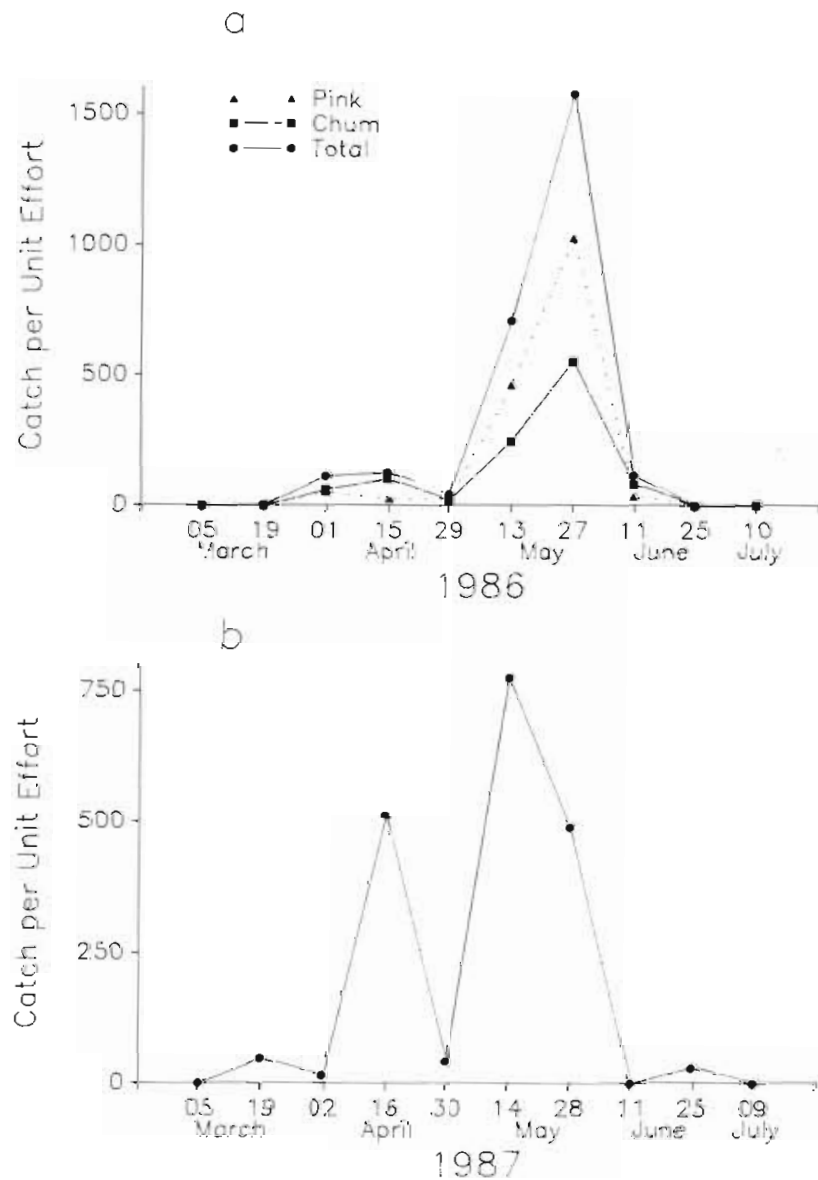

Fig. 3. Oncorhynchus keta and O. gorbuscha. Catch per Unit Effort (number in 3 beach seine sets) at Stn $F$ of (a) juvenile chum and pink salmon in 1986, and (b) juvenile chum salmon in 1987

while pink formed a greater proportion of the May samples. Chum were found to consume similar numbers of the 3 target harpacticoid species to pink salmon except on June 11, when chum consumed significantly (Student's $t$-test, $p<0.05$ ) more Zaus aurelii than pink salmon. Since the diets were so similar, the data from both species were pooled. In 1987, juvenile chum abundance also peaked in May (Fig. 3b). Low numbers were captured in June 1987, similar to 1986, but abundance in April 1987 was proportionately higher than in 1986. In both years, food weight expressed as a percentage of body weight of the fish varied over the sampling season but high values were always observed during the periods of peak fish abundance (Fig. 4).

The vast majority of harpacticoids consumed by juvenile salmon were Harpacticus uniremis, Tisbe cf. furcata, and Zaus aureliu ( $>75 \%$ by numbers in both years) (Table 2). Adult females of all 3 species were the dominant copepodite stage observed in gut contents on all sampling dates in both years (Table 3 ).

In 1986, consumption of adults and potential adults (both genders) of Harpacticus uniremis was high from April 28 to June 10 (Fig. 5). Comparison of $95 \%$ confjdence limits indicates the measurements were not different. Adult and potential adult male consumption was significantly lower than that of adult and potential adult females after May 26. Copepod mortality rates, however, were highest for adult and potential adult females between April 28 and May 12 and then
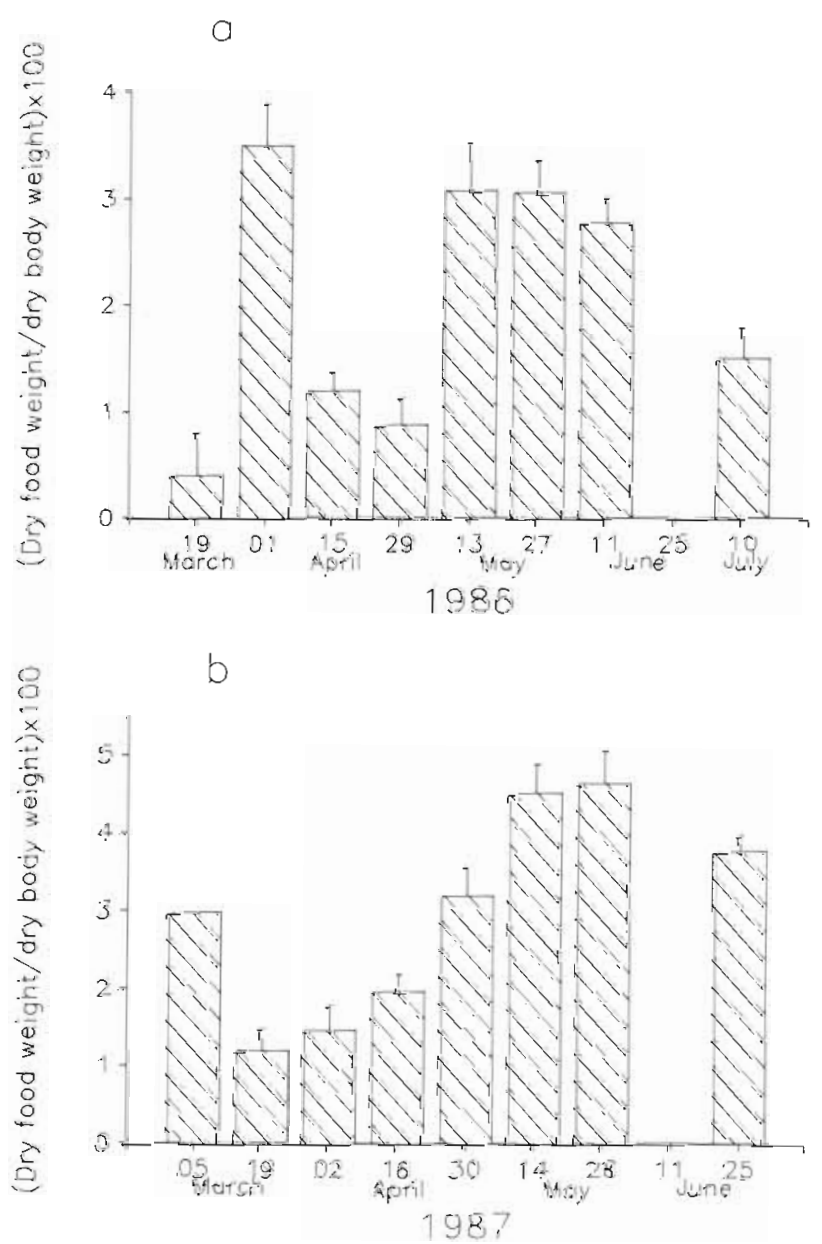

Fig. 4. Oncorhynchus keta and $O$. gorbuscha. Food weight as a percentage of body weight at Stn $F$ for (a) juvenile chum and pink salmon in 1986, and (b) juvenile chum salmon in 1987. Values are means \pm 1 standard error, $n=20$, except for (a): March 19, $\mathrm{n}=3$; July 10, $\mathrm{n}=4$; and (b): March 5, $\mathrm{n}=1$; April 2, $\mathrm{n}=15$ 
Table 2. Oncorhynchus keta and O. gorbuscha. Numbers and proportions of Harpacticus uniremis (H), Tisbe cf. furcata (T), Zaus aurelii (Z) and other harpacticoid copepod species found in the gut contents of sampled juvenile chum and/or pink salmon in 1986 and 1987. Total: total number of harpacticoids in all sampled fish

\begin{tabular}{|cccccccc}
\hline Year & Fish & Total & H & T & Z & Others \\
\hline 1986 & 127 & 30407 & $7720(25.4 \%)$ & $5980(19.7 \%)$ & $9538(31.4 \%)$ & $7169(23.6 \%)$ \\
1987 & 136 & 35924 & $15838(44.1 \%)$ & $8866(24.7 \%)$ & $4557(12.7 \%)$ & $6663(18.5 \%)$ \\
\hline
\end{tabular}

Table 3. Oncorhynchus keta and O. gorbuscha. Percent composition of adult females, males and individual juvenile copepodite stages of Harpacticus uniremis $(\mathrm{H})$, Tisbe cf. furcata $(\mathrm{T})$ and Zaus aurelii $(\mathrm{Z})$ in gut contents of sampled juvenile chum and/or pink salmon in 1986 and 1987. Values are the mean and standard error of the percent composition of each stage in the fish samples on each sampling date where the copepod species was found in the gut contents. $\mathrm{n}$ : sample size; C6F: adult female; C6M: adult male; $\mathrm{C} 1$ to $\mathrm{C} 5$ : Copepodites 1 to 5

\begin{tabular}{|c|c|c|c|c|c|c|c|}
\hline \multirow[t]{2}{*}{ Copepod } & \multicolumn{7}{|c|}{ Stage } \\
\hline & $\mathrm{C} 6 \mathrm{~F}$ & $\mathrm{C} 6 \mathrm{M}$ & C5 & $\mathrm{C} 4$ & $\mathrm{C} 3$ & $\mathrm{C} 2$ & C1 \\
\hline \multicolumn{8}{|l|}{1986} \\
\hline $\mathrm{H}(\mathrm{n}=8)$ & $55.9 \pm 9.30$ & $26.9 \pm 5.61$ & $11.0 \pm 4.49$ & $4.90 \pm 2.08$ & $<1$ & $<1$ & $<1$ \\
\hline$T(n=7)$ & $94.9 \pm 3.59$ & $5.05 \pm 3.59$ & 0 & 0 & 0 & 0 & 0 \\
\hline $\mathrm{Z}(\mathrm{n}=7)$ & $98.3 \pm 0.728$ & $1.63 \pm 0.701$ & $<1$ & $<1$ & 0 & $<1$ & 0 \\
\hline \multicolumn{8}{|l|}{1987} \\
\hline $\mathrm{H}(\mathrm{n}=8)$ & $55.6 \pm 8.72$ & $33.5 \pm 5.29$ & $3.57 \pm 1.76$ & $4.68 \pm 2.57$ & $1.87 \pm 0.760$ & $<1$ & $<1$ \\
\hline$T(n=7)$ & $94.1 \pm 1.56$ & $5.15 \pm 1.29$ & $<1$ & $<1$ & 0 & 0 & 0 \\
\hline $\mathrm{Z}(\mathrm{n}=7)$ & $99.2 \pm 0.422$ & $<1$ & $<1$ & 0 & $<1$ & 0 & 0 \\
\hline
\end{tabular}

declined (Fig. 5b). Adult and potential adult male mortality rates were only high between May 26 and June 10 and were higher than those for females. In 1987, consumption rates of adult and potential adult females and males by the fish were elevated, fairly constant and not different between genders from April 2 to June 11 (Fig. 6a). However, high mortality of both genders was limited to the period from May 14 to 28 (Fig. 6b).

Tisbe cf. furcata adult and potential adult consumption by juvenile salmon in 1986 was highest from April 28 to May 26, with consumption of females greater than males (Fig. 7a). Adult and potential adult copepod mortality during this period was also high, but lower than a previous peak from March 18 to 31 (Fig. 7b). Adult and potential adult male mortality appeared to be larger than female between May 12 and 26. In 1987, consumption of Tisbe was high between April 30 and June 11 (Fig. 8a). Adult and potential adult female consumption was greater between May 14 and 28 than in the preceding and following intervals. Adult and potential adult female consumption was greater than male consumption during this period. Mortality of adults and potential adults was only high between May 14 and June 11 with male mortality slightly higher than female (Fig. 8b).

For both genders of Zaus aurelii in 1986, consumption rates were highest and equal for adults and potential adults between May 12 and June 10 (Fig. 9a). Female consumption was much greater than male. However, mortality rates were only high for adult and potential adult females between April 14 and May 12 while male mortality was high between April 28 and May 12 (Fig. 9b). In 1987, consumption rates were largest and not different between the 2 periods for either gender of adults and potential adults between May 14 and June 11 (Fig. 10a). Female consumption was larger than male. Mortality rates were high only between May 28 and June 11 with adult and potential adult female mortality just slightly greater than male (Fig. 10b).

\section{DISCUSSION}

As has been previously documented at this study site (D'Amours 1987), juvenile salmonids consume large numbers of harpacticoid copepods, especially the primarily epiphytic species Harpacticus uniremis, Tisbe cf. furcata and Zaus aurelii (Webb 1989). Juvenile chum salmon gut contents generally did not differ from those of juvenile pink in 1986 with respect to these 3 species. Also, food weight as a percentage of body weight was high at periods of maximal fish density. This is contradictory to the results of Healey (1979) for juvenile chum in the Nanaimo estuary but supports the analyses of a juvenile chum and pink 'fullness index' in Alaska (Cordell 1986). The lack of a 
$a$
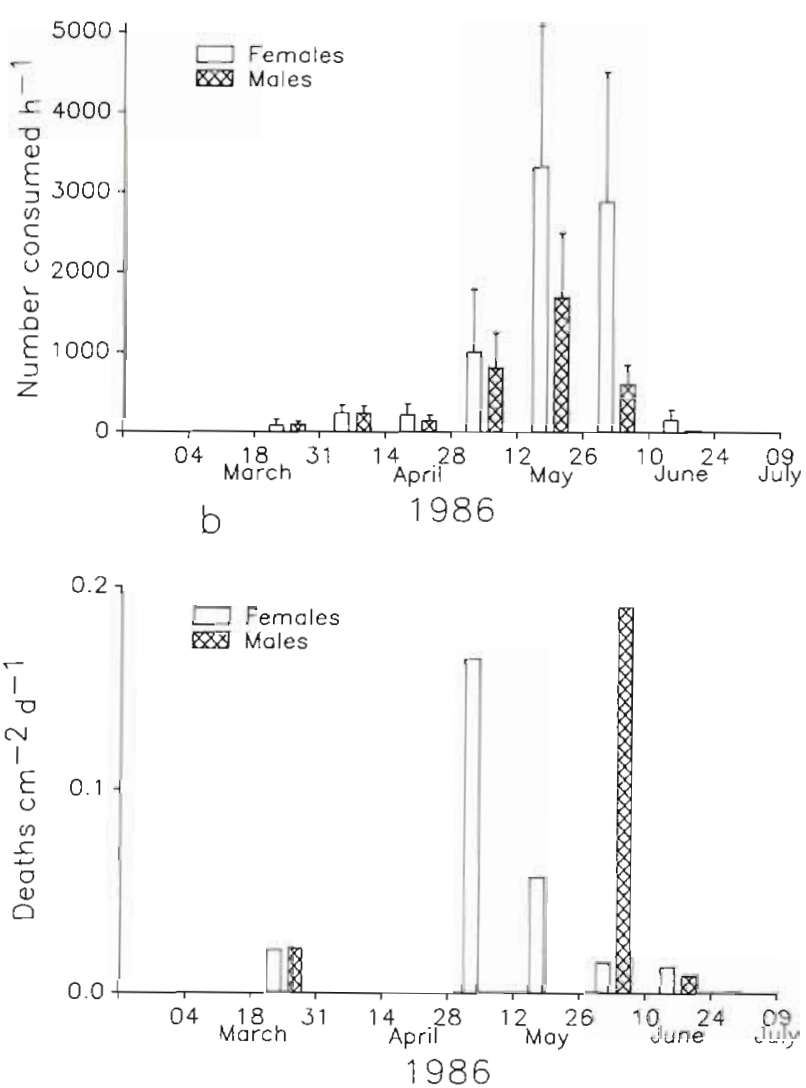

Fig. 5. (a) Oncorhynchus keta and $O$. gorbuscha. Consumption index (number consumed $\mathrm{h}^{-1}$ ) of male and female adult and potential adult Harpacticus uniremis by juvenile chum and pink salmon in 1986. (b) Male and female adult and potential adult mortality (deaths $\mathrm{cm}^{-2} \mathrm{~d}^{-1}$ ) of $H$. uniremis in 1986. Error bars in (a) are approximate $95 \%$ confidence limits

decrease in relative food weight with juvenile salmonid density suggests that fish density did not affect food intake.

The adult and potential adult copepod mortality model used here appears to be robust and is unhindered in application by avoiding detailed analysis of stage-specific mortality of juveniles (e.g. Ohman 1986). Coupled with the accurate estimates of harpacticoid density obtained using intrashoot distributions (Webb 1989, 1990), valid temporal patterns of mortality of Harpacticus uniremis, Tisbe cf. furcata and Zaus aurelii were obtained. An index of gender-specific consumption rates of 3 harpacticoid species was calculated using estimates of juvenile salmonid abundance, analysis of gut contents, diurnal feeding patterns and gut evacuation rates (Webb 1989). While determination of consumption rates on an areal basis was logistically impossible in this study (mark-recapture experiments would have required enormous numbers of marked fish given previous results from this area; Levings et al. a
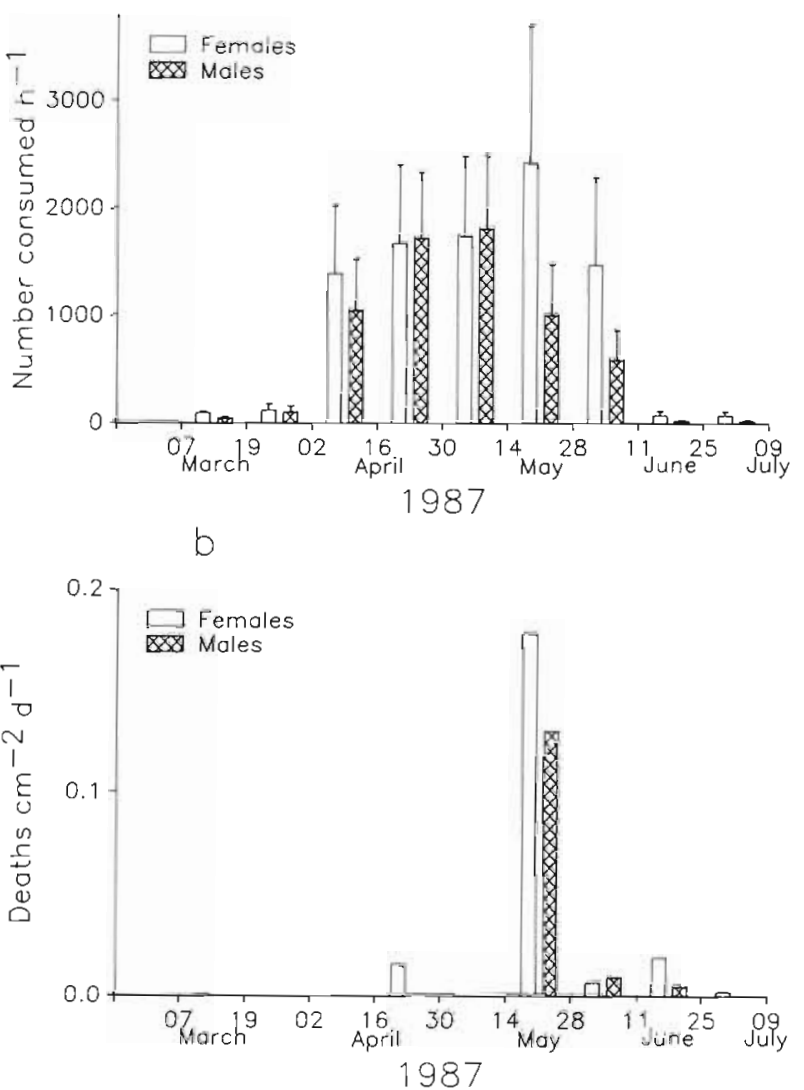

Fig. 6. (a) Oncorhynchus keta. Consumption index (number consumed $\mathrm{h}^{-1}$ ) of male and female adult and potential adult Harpacticus uniremis by juvenile chum salmon in 1987. (b) Male and female adult and potential adult mortality (deaths $\mathrm{cm}^{-2} \mathrm{~d}^{-1}$ ) of $\mathrm{H}$. uniremis in 1987. Error bars in (a) are approximate $95 \%$ conficience limits

1983), temporal patterns in consumption are deemed valid. Therefore, a comparison of patterns of harpacticoid mortality and salmonid consumption provides a true assessment of the impact of salmonid predation on the populations of $H$. uniremis, $T$. cf. furcata and $Z$. aurelii.

Juvenile chum and pink salmon predation does not appear to control the abundance cycles of Harpacticus uniremis, Tisbe cf. furcata and Zaus aurelii. Consumption was out of phase with the major period of mortality for $H$. uniremis, $T$. cf. furcata and $Z$. aurelii in both years. Also, relative male and female mortality did not correspond to relative consumption rates. In 1986, female $H$. uniremis mortality was declining while salmonid consumption was at its highest. Male mortality was highest while consumption was decreasing. In 1987, salmonid consumption of both genders was high and fairly constant for 2 mo while the major mortality occurred in a $2 \mathrm{wk}$ period. The major period of $T$. cf. furcata mortality occurred in March in 1986, whereas 

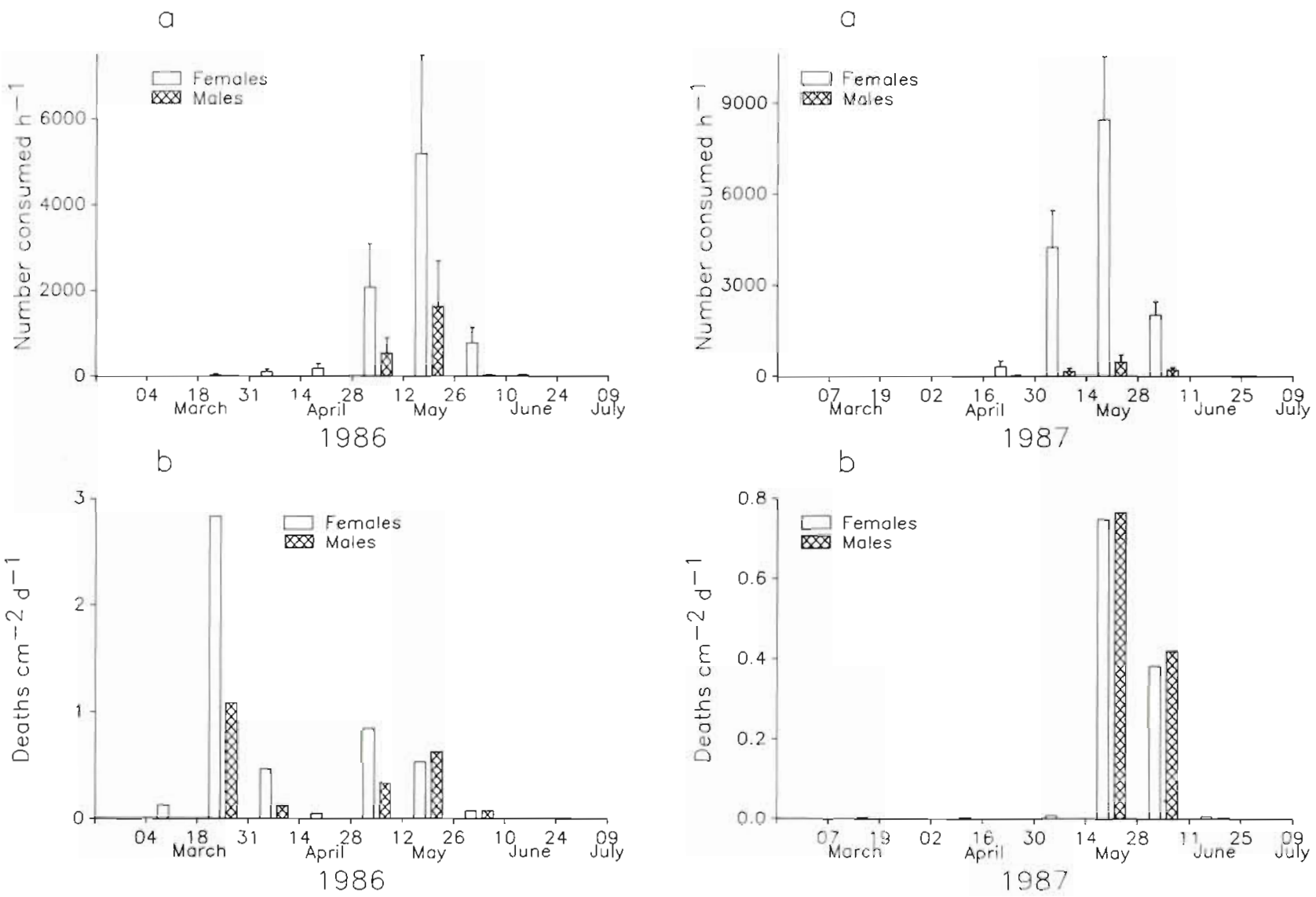

Fig. 7. (a) Oncorhynchus keta and O. gorbuscha. Consumption index (number consumed $\mathrm{h}^{-1}$ ) of male and female adult and potential adult Tisbe cf. furcata by juvenile chum and pink salmon in 1986. (b) Male and female adult and potential adult mortality (deaths $\mathrm{cm}^{-2} \mathrm{~d}^{-1}$ ) of $T$. cf. furcata in 1986. Error bars in (a) are approximate $95 \%$ confidence limits

consumption levels did not rise until after late April. Also, male mortality was higher than female in midMay but male consumption was low. In 1987, consumption started to rise in mid-April but mortality did not markedly increase until mid-May. Male mortality appeared higher than female but male consumption was significantly lower than female. For $Z$. aurelii in 1986, high mortality preceded high consumption by a month for both males and females while in 1987 high mortality occurred later than the consumption maximum. Also, in 1987 mainly female consumption was observed while male mortality was nearly as high as female. Even considering potential underestimates of recruitment later in the sampling season, mortality and consumption patterns of the copepod species would not converge. Therefore, it appears unlikely that juvenile salmonid predation caused the decline in these 3 copepod species.

Since there was little correspondence between juvenile salmonid consumption and harpacticoid mor-

Fig. 8. (a) Oncorhynchus keta. Consumption index (number consumed $\mathrm{h}^{-1}$ ) of male and female adult and potential adult Tisbe cf. furcata by juvenile chum salmon in 1987. (b) Male and female adult and potential adult mortality (deaths $\mathrm{cm}^{-2}$ $\mathrm{d}^{-1}$ ) of $T$ cf. furcata in 1987. Error bars in (a) are approximate $95 \%$ confidence limits

tality, Healey's (1979) suggestion that chum predation caused a decline in Harpacticus uniremis appears to be a coincidence of timing and also perhaps due to an underestimate of Harpacticus abundance. Indeed, although maximum densities obtained from sediment cores were $6.6 \mathrm{~cm}^{-2}$ at one station in the Nanaimo estuary (Sibert 1979), at 6 other stations maximum $H$. uniremis abundance was $<2 \mathrm{~cm}^{-2}$. These densities are, on average, lower than those found at this study site when leaf and sediment densities are summed (Webb 1989). The results of the present study are the first real test of the impact of juvenile salmonid predation on selected harpacticoid copepod species. They support the suggestion by Cordell (1986) that juvenile salmon do not directly determine harpacticoid community structure.

In other studies, the effect of predation by fish on harpacticoid copepods has generally also been small. Alheit \& Scheibel (1982) observed that $90 \%$ of harpacticoids eaten by grunts in a Bermudan lagoon were one 


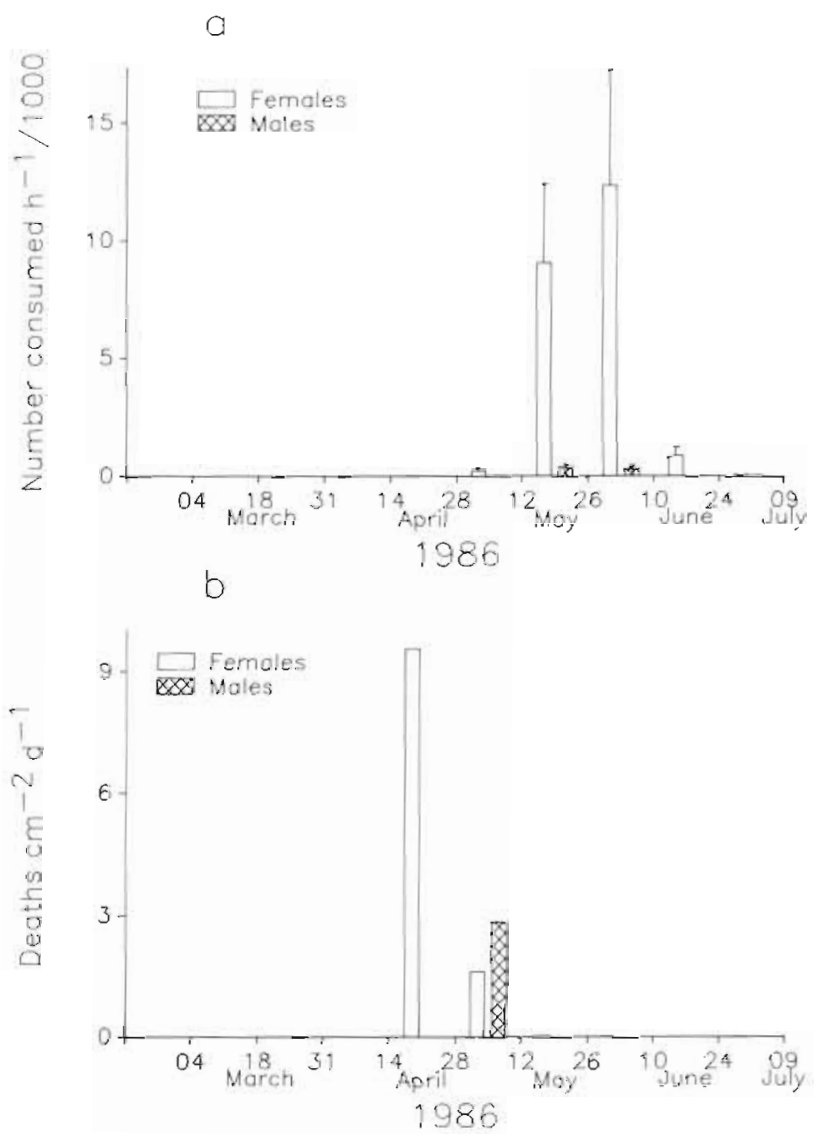

Fig. 9. (a) Oncorhynchus keta and O. gorbuscha. Consumption index (number consumed $\mathrm{h}^{-1}$ ) of male and female adult and potential adult Zaus aurelii by juvenile chum and pink salmon in 1986. (b) Male and female adult and potential adult mortality (deaths $\mathrm{cm}^{-2} \mathrm{~d}^{-1}$ ) of $Z$. aurelii in 1986. Error bars in (a) are approximate $95 \%$ confidence limits

species. However, only $0.1 \%$ of the population was estimated to be removed per day. Amphiascus lobatus Hicks is selectively preyed upon by a blennioid fish in mid to high intertidal rock pools in New Zealand but the habitat complexity of tufted coralline algae provides this epiphytic copepod with a refuge from fish predators (Coull \& Wells 1983). Hicks (1985b) estimated only $0.38 \%$ of the population of Parastenhelia megarostrum Wells, Hicks \& Coull was consumed per day by newly settled flatfish in New Zealand. Predator cage inclusion experiments with gobies on an English mudfiat yielded little observable effect on total harpacticoid numbers in the sediment but indicated shifts in species dominance (Gee et al. 1985). Gee (1987), by estimating consumption of the surficial harpacticoid Asellopsis intermedia (T. Scott) by flatfish and gobies and comparing estimated values to reductions in copepod population density, found that the effect of fish predation was small compared to that of other predators (e.g. shrimp).

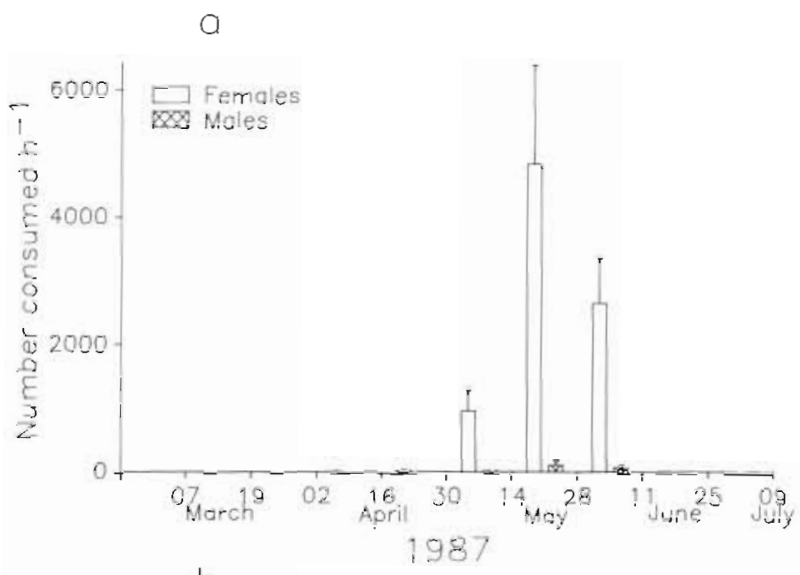

b

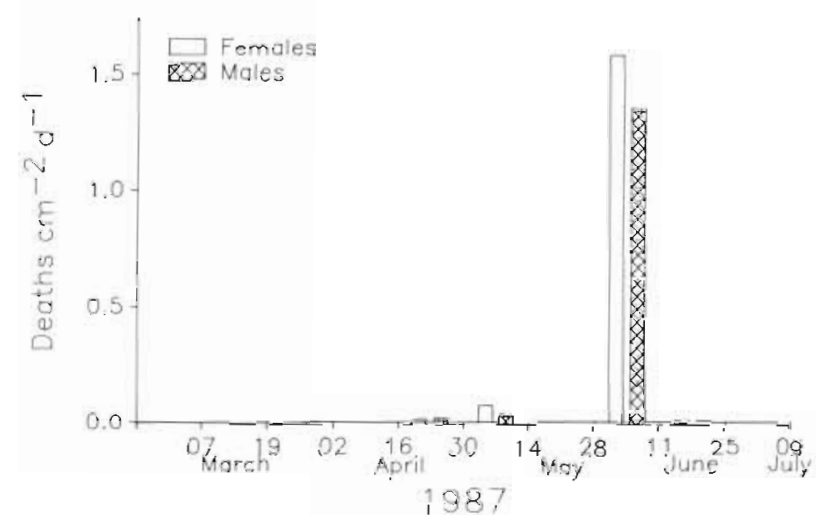

Fig. 10. (a) Oncorhynchus keta. Consumption index (number consumed $\mathrm{h}^{-1}$ ) of male and female adult and potential adult Zaus aurelii by juvenile chum salmon in 1987. (b) Male and female adult and potential adult mortality (deaths $\mathrm{cm}^{-2} \mathrm{~d}^{-1}$ ) of Z. aurelii in 1987 Error bars in (a) are approximate $95 \%$ confidence limits

This paper has dealt with the analysis of descriptive, observational data. While the conclusions reached herein seem valid, it is impossible to attach any statistical significance to the differences in patterns of fish consumption and copepod mortality, based on the generated analysis. However, a companion paper (Webb 1991) presents the results of a manipulative field experiment carried out in 1986 and 1987 at the same site to determine the response of the harpacticoid community when large epibenthic predators, such as juvenile salmon, are excluded from portions of the seagrass bed.

Acknowledgements. I am indebted to D. DAmours, M. St. John and $M$. Gollner for their assistance with the field sampling. J. Stalzer of Westshore Terminals Ltd kindly provided access to company property for beach seining. A. Metaxas, D. D'Amours, T.R. Parsons, S.S. Bell, T.F. Pedersen, N.J. Wilimovsky, P. G. Harrison, P.J. Harrison and 3 anonymous reviewers all provided constructive criticism of the research and/or the manuscript. W. P. Cochlan applied his artistry to Fig. 1. Logistical support for this study was provided by 
NSERC Operating Grants to T.R. Parsons. Personal support was provided by a NSERC Postgraduate Scholarship, Fonds FCAC (Quebec), the Kit Malkin Scholarship, a Summer University of British Columbia Graduate Fellowship and the Capt. T.H. Byrne Scholarship to the author and NSERC Operating Grants to T.R. Parsons.

\section{LITERATURE CITED}

Alheit, J., Scheibel, W. (1982). Benthic harpacticoids as a food source for fish. Mar. Biol. 70: 141-147

Argentisi, F., De Bernardi, R., Di Cola, G. (1974). Mathematical models for the analysis of population dynamics in species with continuous recruitment. Memorie Ist. ital. Idrobiol. 31: 245-275

Bax, N. J. (1983). The early marine migration of juvenile chum salmon (Oncorhynchus keta) through Hood Canal - its variability and consequences. Ph. D. thesis, University of Washington, Seattle

Bell, S. S., Hicks, G. R. F., Walters, K. (1988). Active swimming in meiobenthic copepods of seagrass beds: geographic comparisons of abundances and reproductive characteristics. Mar. Biol. 98: 351-358

Bergmans, M. (1981). A demographic study of the life cycle of Tisbe furcata (Baird, 1837) (Copepoda, Harpacticoida). J. mar. Biol. Ass. UK 61: 691-705

Cordell, J. R. (1986). Structure and dynamics of an epibenthic harpacticoid assemblage and the role of predation by juvenile salmon. M.S. thesis, University of Washington, Seattle

Coull, B. C., Wells, J. B. J. (1983). Refuges from fish predation: experiments with phytal meiofauna from the New Zealand rocky intertidal. Ecology 64: 1599-1609

D'Amours, D. (1987). Trophic phasing of juvenile chum salmon Oncorhynchus keta Walbaum and harpacticoid copepods in the Fraser River Estuary, British Columbia. Ph. D. thesis, University of British Columbia, Vancouver

D'Amours, D. (1988). Vertical distribution and abundance of natant harpacticoid copepods on a vegetated tidal flat. Neth. J. Sea Res. 22: 161-170

Feller, R. J., Kaczynski, V W. (1975). Size selective predation by juvenile chum salmon (Oncorhynchus keta) on epibenthic prey in Puget Sound. J. Fish. Res. Bd Can. 32: $1419-1429$

Gee, J. M. (1987). Impact of epibenthic predation on estuarine intertidal harpacticoid copepod populations. Mar. Biol. 96: $497-510$

Gee, J. M., Warwick, R. M., Davey, J. T., George, C. L. (1985). Field experiments on the role of epibenthic predators in determining prey densities in an estuarine mudflat. Estuar coast. Shelf Sci. 21: 429-448

Godin, J.-G. J. (1981). Daily patterns of feeding behavior, daily rations, and diets of juvenile pink salmon (Oncorhynchus gorbuscha) in two marine bays of British Columbia. Can. J. Fish. Aquat. Sci. 38: 10-15

Gordon, D. K., Levings, C. D. (1984). Seasonal changes of inshore fish populations on Sturgeon and Roberts Bank, Fraser River estuary, British Columbia. Can. Tech. Rep. Fish. Aquat. Sci. 1240

Hairston, N. G., Jr., Twombly, S. (1985). Obtaining life table data from cohort analyses: a critique of current methods. Limnol. Oceanogr. 30: 886-893

Harrison, P. G. (1987). Natural expansion and experimental manipulation of seagrass (Zostera spp.) abundance and the response of infaunal invertebrates. Estuar. coast. Shelf Sci. 24: 799-812

Healey, M. C. (1979). Detritus and juvenile salmon production in the Nanaimo estuary: I. Production and feeding rates of juvenile chum salmon (Oncorhynchus keta). J. Fish. Res. Bd Can. 36: 488-496

Healey, M. C. (1980). The ecology of juvenile salmon in Georgia Strait, British Columbia. In: McNeil, W. J., Himsworth, D. C. (ed5.) Salmonid ecosystems of the north Pacific. Oregon State University Press, Corvallis, p. 203-229

Hicks, G. R. F. (1985a). Meiofauna associated with rocky shore algae. In: Moore, P. G., Seed, R. (eds.) The ecology of rocky coasts. Hodder and Stoughton, London, p. 36-56

Hicks, G. R. F. (1985b). Biomass and production estimates for an estuarine meiobenthic copepod, with an instantaneous assessment of exploitation by flatfish predators. N. Z. J. Ecol. 8: 125-127

Kaczynski, V. W., Feller, R. J., Clayton, J., Gerke, R. J. (1973). Trophic analysis of juvenile pink and chum salmon (Oncorhynchus gorbuscha and O. keta) in Puget Sound. J. Fish. Res. Bd Can. 30: 1003-1008

Landry, M. R. (1983). The development of marine calanoid copepods with comment on the isochronal rule. Limnol. Oceanogr. 28: 614-624

Levings, C. D., Greer, C. L., Miller, P. (1983). Results of preliminary mark-recapture experiments with juvenile salmonids on Sturgeon and Roberts Bank. Fraser River estuary. Can. Man. Rep. Fish. Aquat. Sci. 1684

Mason, J. C. (1974). Behavioral ecology of chum salmon fry (Oncorhynchus keta) in a small estuary. J. Fish. Res. Bd Can. 31: 83-92

Naiman, R. J., Sibert, J. R. (1979). Detritus and juvenile salmon production in the Nanaimo estuary: III. Importance of detrital carbon to the estuarine ecosystem. J. Fish. Res. Bd Can. 36: 504-520

Ohman, M. D. (1986). Predator-limited population growth of the copepod Pseudocalanus sp. J. Plankton Res. 8: 673-713

Palmer, M. A. (1988). Dispersal of marine meiofauna: a review and conceptual model explaining passive transport and active emergence with implications for recruitment. Mar. Ecol. Prog. Ser. 48: 81-91

Ricker, W E. (1975). Computation and interpretation of biological statistics of fish populations. Bull. Fish. Res. Bd Can. 191

Sawyer, A. J., Haynes, D. L. (1984). On the nature of error involved in estimating stage-specific survival rates by Southwood's method for a population with overlapping stages. Res. Popul. Ecol. 26: 331-351

Sibert, J. R. (1979). Detritus and juvenile salmon production in the Nanaimo estuary: II. Meiofauna available as food to juvenile chum salmon (Oncorhynchus keta). J. Fish. Res. Bd Can. 36: 497-503

Simenstad, C. A., Fresh, K. L., Salo, E. O. (1982). The role of Puget Sound and Washington coastal estuaries in the life history of Pacific salmon: an unappreciated function. In: Kennedy, V S. (ed.) Estuarine comparisons. Academic Press, New York, p. 343-364

Southwood, T. R. E. (1978). Ecological methods, 2nd edn. Chapman and Hall Ltd, London

Swinbanks, D. D., Luternauer, J. L. (1987). Burrow distribution of Thalassinidean shrimp on a Fraser delta tidal flat, British Columbia. J. Paleontol. 61: 315-332

Walters, K. (1988). Diel vertical migration of sediment-associated meiofauna in subtropical sand and seagrass habitats. J. exp. mar. Biol. Ecol. 117: 169-186

Webb, D. G. (1989). Predation by juvenile salmonids on harpacticoid copepods in a shallow subtidal seagrass bed: 
effects on copepod community structure and dynamics. Ph. D. thesis, University of British Columbia, Vancouver Webb, D. G. (1990). Intrashoot distributions of leaf dwelling harpacticoid copepods on the seagrass Zostera marina $L$.: implications for sampling design. Hydrobiologia 206: 155-162

Webb, D. G. (1991). Effect of predation by juvenile Pacific salmon on marine harpacticoid copepods. II. Preda-

This article was submitted to the editor tor density manipulation experiments. Mar. Ecol. Prog. Ser 72: 37-47

Webb, D. G., Parsons, T R. (1988). Empirical analysis of the effect of temperature on marine harpacticoid copepod development time. Can. J. Zool. 66: 1376-1381

Wilkinson, L. (1985). SYSTAT The system for statistics. Version 2.1. Systat, Inc, 1800 Sherman Ave, Evanston, Illinois 60201, USA.

Manuscript first received: June 22, 1990

Revised version accepted: January 29, 1991 